\title{
Where they lived
}

\author{
Lived in London: Blue Plaques and the \\ Stories Behind Them \\ Edited by Emily Cole \\ Yale University Press: 2009. 637 pp. \\ $\$ 85, £ 40$
}

When Einstein died in 1955, The Washington Post published a cartoon that has since become famous. It shows Earth floating among the other planets and heavenly bodies, with a sign tacked on to it bearing the words "ALBERT EINSTEIN LIVED HERE".

Famous past residents of London are similarly recalled by a series of circular blue plaques that adorn their one-time mansions, houses and flats. The scheme has been imitated by major cities around the world. Their stories are told in a new complete illustrated guide, Lived in London, which documents recipients street by street, square by square. Yet, less than a tenth are scientists. Of around 800 people who are commemorated with plaques, 58 are scientists, along with 44 medics, 17 engineers and 15 others associated with industry and invention. This suggests some bias against recognizing scientists beyond a charmed circle of celebrities - there are 194 plaques for literary figures.

Significantly, the first scientist to be honoured was Benjamin Franklin, who was a prominent statesman as well as a prominent scientist. During Franklin's sojourns in London, in 1757-62 and 1764-75, accompanied by his son and their two slaves, he was the agent of the Pennsylvania Assembly, charged with encouraging pro-American sympathies in the run-up to the Declaration of Independence.

Isaac Newton, like Franklin, lived in the city for a long period but did his best scientific work elsewhere. Michael Faraday, Christopher Wren and Norman Lockyer (the founding editor of Nature) spent almost all of their working lives in London. Others, such as Charles Darwin and the Italian Guglielmo Marconi, made breakthroughs there, but stayed only a short time. Darwin discovered the principle of natural selection while living in Bloomsbury in 1838-42.

The criteria for choosing an individual have inevitably varied since the official system of commemorative plaques, now run by English Heritage, was started by the then Society of Arts (now the Royal Society of Arts) in 1866.

Certain figures, such as Thomas Henry Huxley, were commemorated soon after they died. Nowadays a blue plaque can only be awarded at least 20 years after a person's death. But the main criteria have remained the same. Individuals must be regarded as eminent by fellow professionals and to have made "an important positive contribution to human welfare or happiness". Place of birth or nationality is irrelevant, but they must have resided in London for a significant period - in time or in importance. Finally, either the "well-

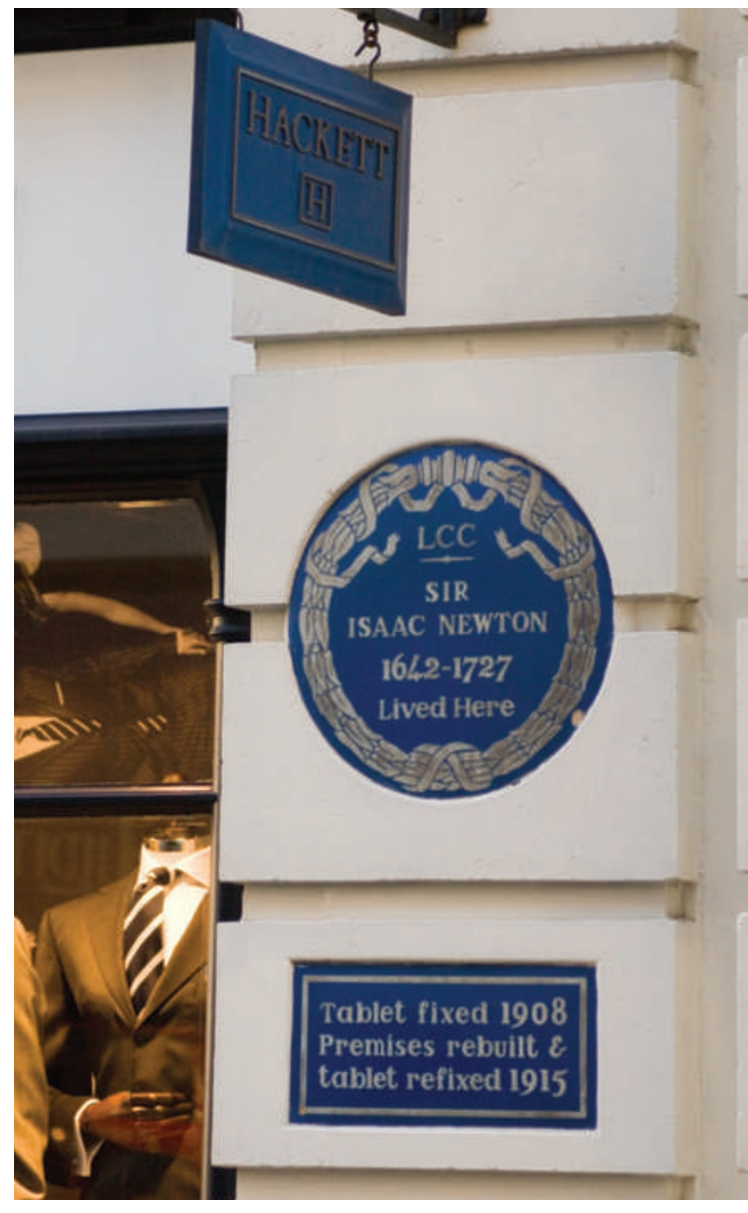

Isaac Newton's former Jermyn Street, London address. informed passer-by" must recognize their name, or they must deserve national recognition. A varied list results.

Despite Henry Cavendish being little known to the public, the house of this great eighteenth-century experimental physicist is marked in Bloomsbury's Bedford Square. Here he established his collection of minerals and a semi-public library of some 12,000 volumes. His private laboratory was at
Clapham Common in south London. Cavendish, the book reports, was "taciturn to the point of Trappism", and communicated with his three servants by note.

H. G. Wells, by contrast, had massive name recognition but lack of approbation from scientists. By the time he moved into his house near Regent's Park in 1936, Wells was one of the most famous writers in the world, partly through his science fiction, such as The Time Machine, partly through best-selling nonfiction such as The Outline of History. Despite his claim that his house was "tumble-down" in a self-composed obituary, its luxuries included a four-poster bed and a private telephone exchange. Wells never received the Fellowship of the Royal Society that he felt was his due, and publicly referred to the fellows as "a lot of bastards".

Between these two poles, there is much scope for differences of opinion. Physicist and inventor Charles Wheatstone, who died in 1875, was initially rejected for a blue plaque in 1906 despite his contributions to telegraphy and the measurement of electrical resistance - using the 'Wheatstone bridge'. In the end, the proposal was successful, revived not by a scientist but by a member of the International Concertina Association, who drew attention to Wheatstone's invention of the instrument, which he patented in 1844.

Lived in London groups the plaques by borough or district, rather than by alphabetical order of recipient, and includes short biographies. These are a welljudged mixture of facts, achievements, anecdotes and quotations, covering the person's entire life, not just their time in London. Of the 'names' with whom I am most familiar, the nineteenth-century physicist, physician and polymath Thomas Young has an exemplary entry, but the book misses the fact that architect and archaeological decipherer Michael Ventris deciphered Minoan Linear B in a flat in Highgate before he moved to the house in neighbouring Hampstead to which his plaque is attached.

Einstein, alas, never lived in London, despite making influential visits there. So there can be no plaque for him. But for others who stayed longer in the city, the blue plaques offer a simple but effective way of bringing past scientific achievements alive to inhabitants and visitors alike.

Andrew Robinson is the author of The Last Man Who Knew Everything, a biography of Thomas Young, and The Man Who Deciphered Linear B, a biography of Michael Ventris.

e-mail: ar471@cam.ac.uk 